See discussions, stats, and author profiles for this publication at: https://www.researchgate.net/publication/335635445

\title{
Design for manufacture and assembly in construction: a review
}

Article in Building Research and Information · December 2019

DOI: 10.1080/09613218.2019.1660608

CITATIONS

2

3 authors:

Gao Shang

University of Melbourne

39 PUBLICATIONS 392 CITATIONS

SEE PROFILE

20 Weisheng Lu

The University of Hong Kong

197 PUBLICATIONS 3,587 CITATIONS

SEE PROFILE

Some of the authors of this publication are also working on these related projects:

Changing cities View project

Content analysis of construction documents using semantic similarity models View project 85 PUBLICATIONS 642 CITATIONS

SEE PROFILE 


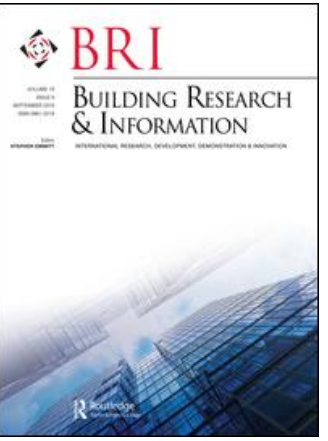

Building Research \& Information

\section{Design for manufacture and assembly in construction: a review}

\section{Shang Gao, Ruoyu Jin \& Weisheng Lu}

To cite this article: Shang Gao, Ruoyu Jin \& Weisheng Lu (2019): Design for manufacture and assembly in construction: a review, Building Research \& Information, DOI: 10.1080/09613218.2019.1660608

To link to this article: https://doi.org/10.1080/09613218.2019.1660608

册Published online: 05 Sep 2019.

Submit your article to this journal $\asymp$

View related articles $\widetilde{\nearrow}$

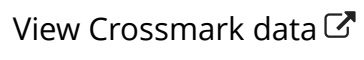




\title{
Design for manufacture and assembly in construction: a review
}

\author{
Shang Gao $\mathbb{B}^{\mathrm{a}}$, Ruoyu Jin $\mathbb{1}^{\mathrm{b}}$ and Weisheng $\mathrm{Lu}^{\mathrm{c}}$ \\ ${ }^{\mathrm{a}}$ Faculty of Architecture, Building and Planning, The University of Melbourne, Melbourne, Australia; ${ }^{\mathrm{b}}$ Division of Built Environment and Civil \\ Engineering, School of Environment and Technology, University of Brighton, Brighton, UK; ' $D e p a r t m e n t$ of Real Estate and Construction, Hong \\ Kong University, Hongkong, People's Republic of China
}

\begin{abstract}
Design for Manufacture and Assembly (DFMA) is known as both a philosophy and a methodology whereby products are designed in a way that is as amenable as possible for downstream manufacturing and assembly. As construction is moving towards a combination of offsite prefabrication and onsite assembly, DfMA is gaining momentum in this heterogeneous industry. Nevertheless, a comprehensive review of DfMA in construction, its prospects and challenges in particular, seems absent from the literature. This study reviews the processes and principles of DfMA and explores the possible perspectives of DfMA with a view to providing implications to the construction industry. It was found that DfMA in construction has been interpreted from three perspectives: (1) a holistic design process that encompasses how structure or object will be manufactured, assembled and guided with DfMA principles; (2) an evaluation system that can work with virtual design and construction (VDC) to evaluate the efficiency of manufacturing and assembly; and (3) a game-changing philosophy that embraces the ever-changing prefabrication and modular construction technologies. This study suggests that development of design guidelines, forming multidisciplinary team, use of VDC systems and understanding the lean principles are factors that could further enhance the successful application of DFMA in construction.
\end{abstract}

\section{ARTICLE HISTORY}

Received 1 May 2019

Accepted 22 August 2019

\section{KEYWORDS}

Design for manufacture and assembly (DfMA); construction; design; prefabrication; assembly; lean construction

\section{Introduction}

Many studies have explored various aspects of prefabrication, or otherwise known as offsite manufacturing, including its business models (Goulding, Rahimian, Arif, \& Sharp, 2015; Pan \& Goodier, 2011), barriers and constraints (Blismas, Pendlebury, Gibb, \& Pasquire, 2005; Mao, Shen, Pan, \& Ye, 2013), benefits (Blismas, Pasquire, \& Gibb, 2006) and opportunities (Arif, Goulding, \& Rahimian, 2012; Goodier \& Gibb, 2007). However, a report from KPMG (2016) cautioned 'offsite manufacturing alone will not overcome the challenges the construction industry is facing, to do so requires a partnership with an integrated design process, like the Design for Manufacture and Assembly (DfMA) method'. DfMA method is commonly known as methodological procedures for evaluating and improving product design for both economic manufacturing and assembly. Unlike the increasing uptake of lean thinking (originated in manufacturing) by construction firms to improve the construction process, very few studies (Fox, Marsh, \& Cockerham, 2001) attempted to shed light on best practices of design engineers, the building designer's counterparts in manufacturing, in the design stage such as the DfMA method. As Dewhurst (2010) noted, 'what we have forgotten along the way is that the design of the product itself ultimately controls the total cost'. DfMA can guide cost reduction efforts early in the product design process, so that product's full potential of lean production can be realized since some potential manufacturing problems and assembly issues have already been addressed in the design. The aim of this paper is to review critically the concepts and principles of DfMA, to discuss the perspectives of DfMA in the construction industry, and to suggest key strategies for better implementation of DfMA in construction.

\section{Review of DfMA}

\section{DfMA: concept}

There are two components of DfMA, design for manufacture (DfM) and design for assembly (DfA) (Bogue, 2012; Otto \& Wood, 2001). DfM is principally concerned with making individual parts, DfA addresses the means of assembling them (Bogue, 2012). The research on DfA is pioneered by Boothroyd and Dewhurst (1987) 
who conducted a series of studies considering the assembly constraints during the design stages. This helps avoid the manufacturing and assembly issues in the downstream stages of the product development (Emmatty \& Sarmah, 2012). Based on the premise that the lowest assembly cost can be achieved by designing a product that can be economically assembled by the most appropriate assembly system. The key principle is to produce a design with fewer parts as well as designing the parts which remain easy to assemble (Stoll, 1986). The fewer the number of parts, the greater is the probability that all of them will be placed correctly (Bridgewater, 1993). To achieve that, Boothroyd and Dewhurst's (1987) handbook introduced various ratings for each part in the assembly process based on the part's ease of handling and insertion. According to Emmatty and Sarmah (2012), the parts do not satisfy the following criteria should be eliminated: (1) the part moves relative to all other parts already assembled during the normal operation of the product; (2) the part must be of a different material, or must be isolated from all other parts already assembled; (3) the part must be separate from all other parts already assembled. In the construction context, the implication of DfA concept is to consider how aspects of the design can be designed in a manner that minimizes work on site, and in particular, avoids 'construction' (RIBA, 2013). An example would be designing a handrail system that allows half landing lengths to be quickly installed into sockets which are pre-positioned in the stair structure (RIBA, 2013).

DfM, on the other hand, compares the use of selected materials and manufacturing processes for the parts of an assembly, determines the cost impact of those materials and processes, and finds the most efficient use of the component design (Ashley, 1995). In Layman's term, DFM aims to design parts that are easier, cheaper and more efficient to manufacture (Emmatty \& Sarmah, 2012). O'Driscoll (2002) defined DfM as the practice of designing products with manufacturing in mind, with its goal is to reduce costs required to manufacture a product. Interestingly, O'Driscoll (2002) argued that the principle of DfM is at least 200 years old, citing LeBlanc, a Frenchman, devised the concept of interchangeable parts in the manufacture of muskets which were previously individually handmade (Bralla, 1999). For construction, DfM is the process of designing in a manner that enables specialist subcontractors to manufacture significant elements of the design in a factory environment (RIBA, 2013). Panelized system such as claddings have been designed in this manner for years, and now the emerging hybrid systems (i.e. pods) and modular buildings (i.e. fully factory-built houses) also pertain to the DfM concept.
From the above descriptions of DfM and DfA, it was felt that these two disciplines are appropriate to be considered together, as one term - DfMA (Bogue, 2012). This is because products now are complex and the ability to assemble them effectively is equally critical. Constance (1992) noted that DfMA was a management and software tool enables designers to consider a product's material selection, design, manufacturability, and assembly up front. Boothroyd (2005) outlined the original DfMA analysis method which provided methodological procedures for evaluating and improving product design for both economic manufacturing and assembly. When DfMA was introduced to manufacturer such as Douglas aircraft in California, it was labelled as a design review method that identified the optimal part design, materials choice, and assembly and fabrication operations to produce an efficient and cost-effective product (Ashley, 1995). The goal is to provide manufacturing input at the conceptualization stage of the design process in a logical and organized fashion.

\section{DfMA: process and principles}

The typical DfMA process can be arranged into stages, as summarized in Figure 1. Boothroyd (1994) has noted that DfA should always be the first consideration, leading to a simplification of the product structure. This is followed by the economic selection of materials and processes and early cost estimates. In this process, cost estimates for original design and new (or improved) design will be compared, in order to make trade-off decision. Once the materials and processes have been finally selected, a more thorough analysis for DfM can be carried out for the detailed design of the parts. At this stage, DfM is assisted with guidelines for standardization, component design and component assembly to reduce total manufacturing cost.

Fox et al. (2001) noted that design engineers are provided with standard design improvement rules or guidelines in workbooks and standard design evaluation metrics in manuals for evaluating a design with respect to its ease of assembly. If a concept is compatible with these guidelines, one can be reasonably assured that the design will be fairly well in the subsequent detailed analysis (Otto \& Wood, 2001). In this manner, a feedback loop is provided to aid designers measuring improvements resulting from specific design changes (Boothroyd, 2005). Afterwards, the best design is taken forward to a more thorough analysis for DfM, where the detailed design for the parts will be performed (Boothroyd, 1994).

According to Bogue (2012), there are three means of applying a DfMA process. The first is to follow a general 


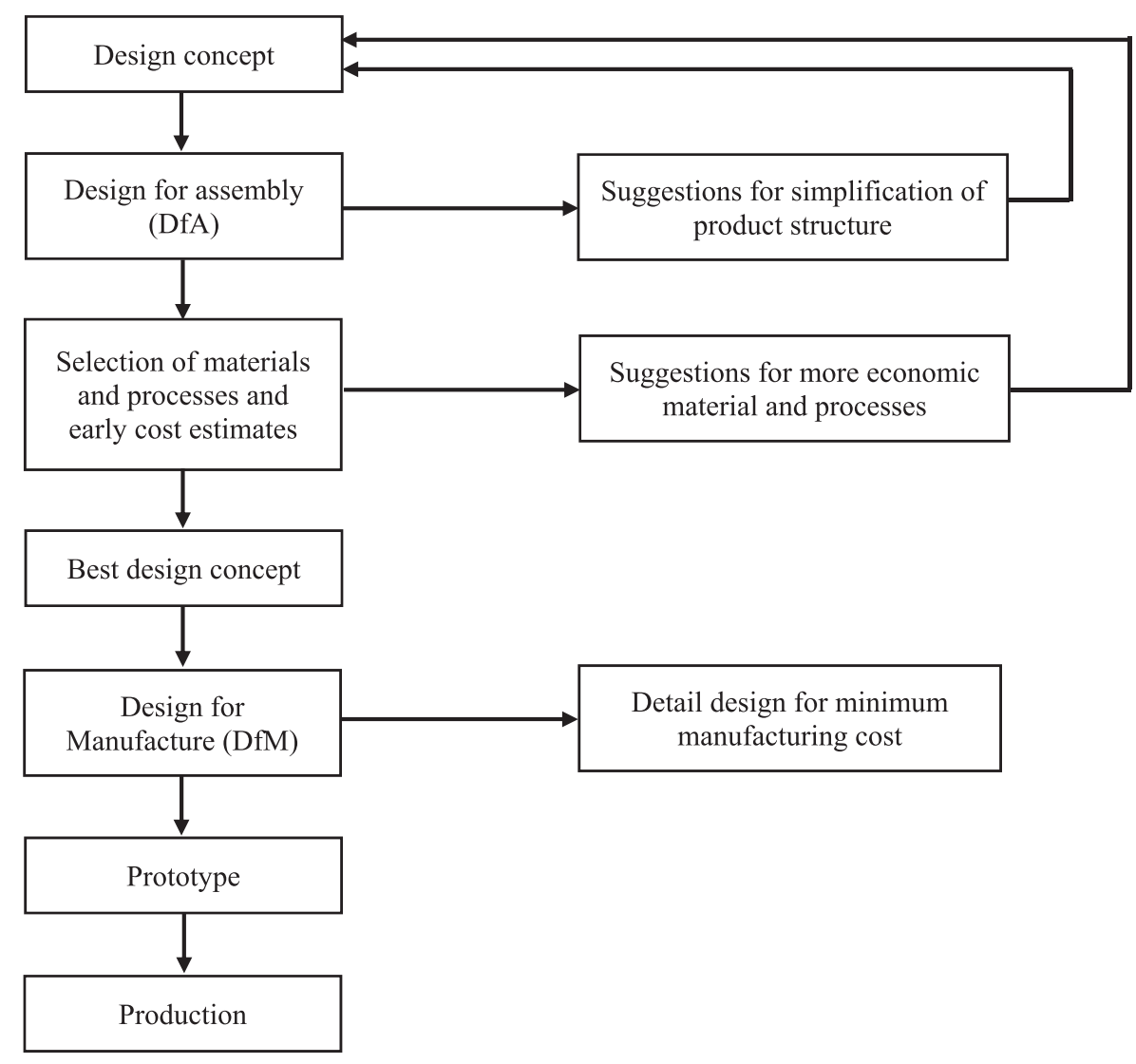

Figure 1. Typical stages in a DfMA procedure. Source: Boothroyd (2005).

set of non-specific and qualitative rules or guidelines and require someone (most likely designers and engineers) to interpret and apply them in each individual case. The aim is to encompass a diversity of products, processes and materials. Table 1 provides an example of such DfMA guidelines and their associated benefits. Similarly, Stoll (1986) outlined ten DfMA principles and rules: (1) minimizing total number of parts, (2) developing a modular design, (3) using standard components, (4) designing parts to be multifunctional, (5) designing parts for multi-use, (6) designing parts for ease of fabrication, (7) avoiding separate fasteners, (8) minimizing assembly directions, (9) maximizing compliance, and (10) minimizing handling.

A close examination reveals that despite these guidelines/principles from various reference points, they share substantial similarities, such as minimization, standardization, and modular design to be the key characteristics of DfMA principles. This is in line with the heuristic principles of Koskela's (2000) flow concept of production: (1) simplify by minimizing the number of steps, parts and linkages, (2) increasing flexibility, and (3) increasing transparency. As Koskela (2000) noted: 'simplification can be realized, on one hand, by eliminating non-value-adding activities from the production process, and on the other hand by reconfiguring value-adding parts or steps'. The implication of this heuristic principle, in the context of DfMA, is for designers to rethink their designs as to what extent the criteria that they applied in their designs would affect the production and assembly that may cause extra motions.

The second method employs a quantitative evaluation of the design. The rationale is that each part of the design can be rated with a numerical value depending on its 'assemblability' (Bogue, 2012). Subsequently, the numbers can be summed for the entire design and the resulting value is used as the guide to evaluate the overall design quality. Another evaluation tool is based on a 100-point method with demerit marks being given for factors which hamper the ease of assembly.

The third approach which is most recently developed is the automation of the entire process. It relies on computer software. Quantitative analysis can be applied to the design, followed by constructing an expert system employing the general design rules. The system can be developed in a way that a design can be analysed, evaluated, and then optimized repeatedly by applying the rules to improve the design quality after each iteration. In this connection, it is particularly important that the DfMA 
Table 1. General DfMA guidelines and their benefits.

\begin{tabular}{|c|c|}
\hline Guidelines & Benefits \\
\hline 1. Minimize the part count & $\begin{array}{l}\text { Improved reliability, reduced } \\
\text { purchasing and inventory costs, } \\
\text { simplified assembly }\end{array}$ \\
\hline $\begin{array}{l}\text { 1. Use standard, off-the-shelf parts } \\
\text { rather than custom components }\end{array}$ & $\begin{array}{l}\text { Reduced costs, lower purchasing } \\
\text { lead times, potentially greater } \\
\text { reliability }\end{array}$ \\
\hline $\begin{array}{l}\text { 1. Minimize and standardize the use } \\
\text { of fasteners/design for efficient } \\
\text { joining and fastening }\end{array}$ & $\begin{array}{l}\text { Reduced costs, simplified assembly, } \\
\text { improved reliability, simplified repair } \\
\text { and maintenance }\end{array}$ \\
\hline $\begin{array}{l}\text { 1. Use as few dissimilar materials as } \\
\text { possible }\end{array}$ & $\begin{array}{l}\text { Simplified jointing, fewer } \\
\text { manufacturing processes }\end{array}$ \\
\hline 1. Minimize the use of fragile parts & $\begin{array}{l}\text { Cost reductions due to fewer part } \\
\text { failures, easier handling and } \\
\text { assembly }\end{array}$ \\
\hline $\begin{array}{l}\text { 1. Do not over-specify tolerances or } \\
\text { surface finish }\end{array}$ & $\begin{array}{l}\text { Easier manufacture and reduced } \\
\text { fabrication costs }\end{array}$ \\
\hline 1. Design for ease of fabrication & $\begin{array}{l}\text { Cost reductions from the elimination } \\
\text { of complex fixtures and tooling }\end{array}$ \\
\hline 1. Consider modular designs & $\begin{array}{l}\text { Reduced costs due to simplified } \\
\text { assembly and test }\end{array}$ \\
\hline 1. Aim for mistake-proof designs & $\begin{array}{l}\text { Cost reductions by eliminating need } \\
\text { to re-work incorrectly assembled } \\
\text { parts }\end{array}$ \\
\hline $\begin{array}{l}\text { 1. Design for simple part orientation } \\
\text { and handling }\end{array}$ & $\begin{array}{l}\text { Cost reductions due to non-value- } \\
\text { added manual effort or dedicated } \\
\text { fixturing }\end{array}$ \\
\hline $\begin{array}{l}\text { 1. Design with predetermined } \\
\text { assembly technique in mind }\end{array}$ & $\begin{array}{l}\text { Cost reductions from use of proven/ } \\
\text { known techniques }\end{array}$ \\
\hline $\begin{array}{l}\text { 1. Consider design for automated/ } \\
\text { robotic assembly }\end{array}$ & $\begin{array}{l}\text { Potential cost reduction over manual } \\
\text { methods }\end{array}$ \\
\hline
\end{tabular}

Source: Bogue (2012).

rule based evaluation tool is linked to a production database (Fox, Marsh, \& Cockerham, 2002).

\section{DfMA in construction: a research gap}

Construction on site is portrayed by Ballard and Howell (1998) as a combination of fabrication and assembly. Industrialization initiatives are believed to be the driver to shift as much work as possible from site construction into shop conditions where it can be done more efficiently (Ballard \& Howell, 1998). The key to mass production in construction is not the continuous assembly line. Rather, it was the complete and consistent interchangeability of parts and the simplicity of attaching them to each other (Crowley, 1998). Since Koskela (1992) brought the production theory into construction, much has been written about the lean concept and lean tools to make the site assembly efficient (Tommelein, 1998). The focus of lean is predominately focused on the construction process. However, discussions around how design or production development contributes to a better manufacturing and assembly were limited, even though Ballard and Howell (1998) described construction is 'essentially a design process in which the facilities designed are rooted-in-place, and thus require site assembly'. Given the limited source of DfMA in the construction literature, this paper attempted to explore what are the emerging interpretations of DfMA in construction, what typical benefits that DfMA could bring to the construction industry along with the challenges associated with the DfMA adoption in construction.

\section{Method}

A study examining the DfMA in construction is overdue. This study uses existing literature to examine the construction perspectives to DfMA concept. As pointed out by (Nakamba, Chan, \& Sharmina, 2017), systematic reviews allow researchers to examine the strength of the published evidence as unbiased as possible. Following on the steps of conducting a systematic literature review outlined by (Tranfield, Denyer, \& Smart, 2003), the first step in the systematic review was to identify the research. Scopus was searched for publications whose topics include at least one of 'design for manufacture and assemble', 'design for manufacture', 'design for assembly', 'DfMA', 'design for construction', and 'construction'. The search was limited to peer-reviewed published articles in English. A total of 232 hits resulted from an initial search for any one instance of the phrases. Next, inclusion and exclusion criteria were set. The former includes (1) Articles must be written in English and produced by peer-reviewed journals; (2) articles that discuss DfMA in the construction industry. On the other hand, the exclusion criteria apply to those studies (1) lack a focus in the construction industry; (2) only focus on DfMA generally; or (3) articles only mentioned DfMA only in passing. Knowing these criteria, the search was performed in March 2019; articles published by then and appearing in the database were considered. After viewing the title, keywords, and abstracts of the 232 articles, 23 of them were retained as matching the topic. Another three papers with similar themes, but for various reasons not returned by the search, were added manually, giving a pool of 26 journal articles. It is worth mentioning that 9 out of 26 articles (34.6\%) were published in the last two years (2018-2019), indicating that DfMA only recently become a popular topic. Our pool is close in size to 30 papers minimum threshold for literature reviews suggested by Wee and Banister (2016). The 26 articles were thoroughly reviewed which leads to the last steps involved analysis and synthesis of the selected literature to identify any 
emerging categories. The next section reports three emerging perspectives of DfMA in construction, along with the typical benefits of implementing DfMA. The discussion section begins with the challenges associated with DfMA implementation, followed by proposing strategies for dealing with challenges.

\section{Findings}

\section{DfMA: a systematic process}

First, DfMA is viewed as a systematic procedure, which can add value to the construction/production process by standardizing component and reducing design variabilities (Goulding et al., 2015). Several research presented their customized DfMA process in different contexts to different components. For example, Pasquire and Connolly (2003) documented a three-step DfMA process that Crown House Engineering ${ }^{1}$ adopted for mechanical services installations.

- Step 1 - It begins with a generic intent to use manufactured components and an understanding of the benefits and limitations of pre-assembly products.

- Step 2 - design process comprises four main activities: (1) understanding the interfaces between the structure and the services ensuring design integration, (2) feasibility study of the selection of products, components and pre-assembly unit system, (3) development of the design process programme and identification of coordination activities, and (4) preparation of manufacturing drawings and involvement of supplier specifications, and the coordination of the manufacturing input.

- Step 3 - the manufacturing phase is the final step which comprises of three activities: (1) factory assembly, (2) releasing the manufactured components by signing-off the production checklists, and (3) on-site installation.

Apart from the documented DfMA process on building services design and assembly, Gerth, Boqvist, Bjelkemyr, and Lindberg (2013), based on the principles of DfMA and lean, developed the 'Design for Construction' (DfC) model which complements the conventional construction process with the following four steps (see Figure 2): (1) specifying customer values and similar previous projects; (2) identifying onsite waste and cost drivers in previous projects; (3) developing criteria to evaluate constructability; and (4) evaluate constructability of the design. The presented steps of DfC method is only taking place in the concept development and design stage, which is in line with the process of DfMA in the manufacturing literature. It is interesting to see this method encourages designers to capture the production experience from past projects and use it during design. It is also worth mentioning that the DFC method has an iterative nature which enables building design to be further improved until it reaches a satisfactory level with regard to the evaluation criteria (Gerth et al., 2013). The imperatives for this process are a team approach or simultaneous engineering, an attitude to resist making irreversible design decisions as long as possible, and a commitment to the continuous optimization of product and process (Luiten \& Fischer, 1998).

Moreover, in the 3D modelling environment, Yuan, Sun, and Wang (2018) also presented a parametric precast component creation process based on DfMA which is running in Revit (i.e. a Building Information Modelling tool). As Yuan et al. (2018) claimed, the first thing of this process is to conduct DfMA analysis so as to timely integrate the detailed information required by manufacture and assembly stages of precast component

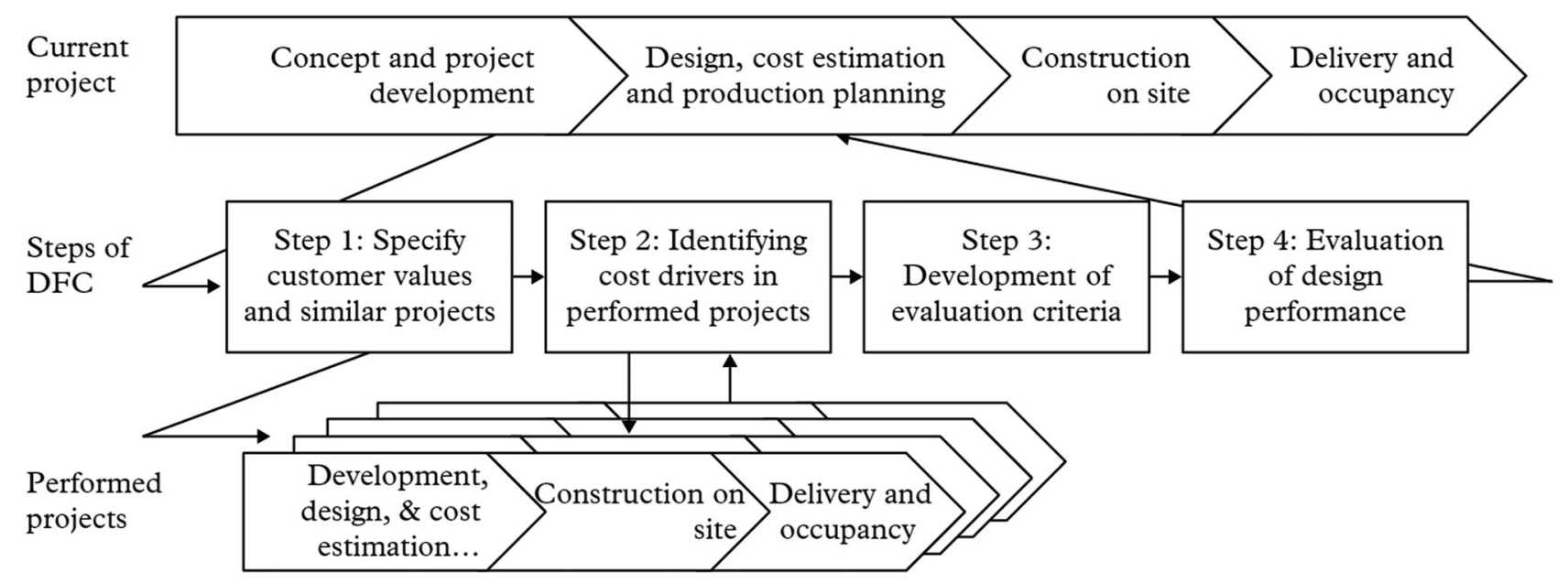

Figure 2. The four steps of DFC and their placement in the housing project process Source: Gerth et al. (2013). 
into the design stage, such as geometry, connection, manufacturing process, assembly process, and mechanical equipment. It is good to have structured steps or guidelines to perform DfMA process given this method is just taking place in the construction industry. It is also noted that a common theme that occurs in these structured processes is the timely feeding and analysis of the information required by manufacture and assembly stages into the design stage. In Luiten and Fischer's (1998) words, DfMA changes the traditional sequential process to a process where design and manufacturing are reciprocally dependent.

\section{DfMA: an evaluation model}

Secondly, DfMA is the development of an evaluation method. Leaney (1996) concluded that the real achievement of DfMA methods is their ability to provide measurements of assemblability which allows objective criteria to be applied in a team-based situation. Hence, calculating an assembly index for each part to see how production cost, time and quality are affected is desired. Leaney (1996) provided insights into three leading DfMA evaluation methods, namely Hitachi method, Boothryd-Dwehurst method, and Lucas method. A comparison of the three methods is summarized in Table 2.

Caution was also voiced out by Leaney (1996) that these methods focused on mechanical based assemblies of a size that could be conveniently assembled at a desk top. It may seem that these methods and procedures are not applicable to products with the size of prefabricated components, or modular units. However, various types of the indices, and evaluation procedures are still worth exploring, which might add value to the body of knowledge in the appraisal method of design performance on downstream construction. Apparently, the closest counterpart of 'assemblability' in construction, is buildability which is regarded as both a 'design method' and a 'design objective' (Fox et al., 2001). Fox et al. (2001) noted 'process complexity is seen as a barrier to defining buildability, and production design procedures associated with buildability remain largely informal and reliant on intuitive application'. Singapore's 'Buildable Design Appraisal System' (BDAS) perhaps is the only tool available to quantify the effect of buildability on construction productivity (Jarkas, 2015). In the BDAS, key components such as structure, and wall components were enumerated with a corresponding laboursaving index. In another word, each value is given to a design choice, and the total value determines the level of buildability. The higher the buildable score would indicate a more efficient use of labour in construction. In the most recent code of practice of buildability (BCA, 2017a), bonus points are allocated for the use of a number of DfMA technologies. The scoring system allows product designer and building designer, in the case of buildability, to take advantage of the opportunity to redesign based on the numerical values. This requires insight and knowledge of the building designers. However, Poh and Chen (1998) clarified that the corresponding labour-saving value for the BDAS is derived from undocumented site productivity studies on various design systems, and represents the aggregated wisdom of a panel of experts. Besides the quantification of buildability in construction, Gerth et al.'s (2013) DfC aims to improve constructability and to minimize the number of components, parts and materials that need to be processed, assembled, and handled onsite. To achieve that, a performance index was created to evaluate to what extent the design could achieve the predefined criteria, which is given a factor of relevance $(\mathrm{R})$, and a grade $(\mathrm{G})$. By multiplying the factor of relevance (R) and the grade $(G)$, the total points $(P)$ is obtained for each criterion. The evaluation is done from a waste creating approach on the premise that each case-specific evaluation criterion can create many types of waste and is

Table 2. Comparison of three different DfMA evaluation methods.

\begin{tabular}{|c|c|c|c|}
\hline $\begin{array}{l}\text { Evaluation } \\
\text { methods }\end{array}$ & Aim & Indices & Key features \\
\hline Hitachi method & $\begin{array}{l}\text { To assess design quality or the difficulty of assembly } \\
\text { operations, and to estimate assembly cost } \\
\text { improvement }\end{array}$ & $\begin{array}{l}\text { Assemblability evaluation score, } \mathrm{E} \\
\text { Estimated assembly cost } \\
\text { ratio, K. }\end{array}$ & $\begin{array}{l}\text { Defining the motions and operations } \\
\text { Filling of a form in the order as the anticipated } \\
\text { assembly sequence }\end{array}$ \\
\hline Lucas DFA & $\begin{array}{l}\text { To assigning and sum penalty factors associated with } \\
\text { potential design problems }\end{array}$ & $\begin{array}{l}\text { Three assemblability indices } \\
\text { Design efficiency } \\
\text { Feeding ration } \\
\text { Fitting ratio }\end{array}$ & $\begin{array}{l}\text { The penalty factors and indices give a relative } \\
\text { measure of assemblability difficulty. } \\
\text { This method is not based on monetary costs }\end{array}$ \\
\hline $\begin{array}{l}\text { Boothryd- } \\
\text { Dwehurst }\end{array}$ & $\begin{array}{l}\text { To establish the cost of handling and inserting } \\
\text { component parts whether this is done manually or } \\
\text { by machines }\end{array}$ & $\begin{array}{l}\text { DFA index } \\
\text { Total number of parts } \\
\text { The ease of handling, insertion, } \\
\text { and fastening of the parts }\end{array}$ & $\begin{array}{l}\text { A paper based evaluation } \\
\text { Answering questions about potential handling } \\
\text { difficulties, size, weight and amount of } \\
\text { orienting } \\
\text { Answering questions about insertion } \\
\text { restrictions }\end{array}$ \\
\hline
\end{tabular}


attached with negative effects (Gerth et al., 2013). A case study of a wall solution can be found in Gerth et al. (2013). Moreover, Gbadamosi et al. (2019) identified a list of assessment criteria - based on the DfMA concept and lean construction principles - for the design optimization of assembly. Factors were identified and prioritized to obtain their weighted importance to the overall assessment system. However, Gbadamosi et al. (2019) study is mainly focusing on the assembly knowledge factors. The identified 14 attributes fall under (1) ease of assembling, (2) ease of handling, (3) speed of assembling, and (4) assembly waste. Yuan et al.'s (2018) work mentioned manufacturing simulation, transportation simulation, and assembly simulation are added into the DfMA-oriented design process. However, the evaluation criteria of the aforementioned simulations are not provided. Yuan et al. (2018) only advised that these simulations should be carried as many as possible to surface potential problems caused by the design. It is reasonable to believe that the sophisticated evaluation criteria should have been programmed into these various sets of simulation software.

\section{DfMA: prefabrication technologies}

Lastly, DfMA was closely associated with prefabrication (Laing O'Rourke, 2013), to which a bundle of gamechanging technologies that can be applied (BCA, 2016). The study of Trinder (2018) involved interviewing senior engineers and managers in the UK water industry, and found three clear themes to identify what they believe DfMA meant for construction, namely (1) off-site, (2) modular, and (3) standardized. The Royal Institute of British Architects (RIBA, 2013) defines DfMA as an approach that facilitates greater offsite manufacturing, thereby minimizing onsite construction. More specifically, the RIBA (2013) noted that DfMA harnesses a wide spectrum of tools and technologies, including (1) volumetric approaches, (2) 'flat pack' solution, ${ }^{2}$ and (3) prefabricated sub-assemblies. Clearly, these themes or technologies are fundamental to modern manufacturing where products are commonly standardized and massproduced off-site (Trinder, 2018). Similarly, in Singapore, the concept was interpreted in a similar fashion. It was first recommended as a key recommendation during the International Panel of Experts (IPE) for Construction Productivity and Prefabrication Technology in 2014, where the panel called for fundamental changes and stronger measures in the 2nd construction productivity roadmap to achieve its target of $20-30 \%$ productivity improvement. This means designing for labour efficient construction, with as much construction works done off-site as possible. Subsequently, BCA showcased some examples of DfMA technology that are commonly used in construction projects (Table 3).

A closer examination of Table 3 shows that the examples of DfMA technology range from material (CLT), to component (integrated prefabricated M\&E), to assembly (precast and prefabricated elements), to module (PBU and PPVC) in about four levels. A comparison of BCA's interpretation of DfMA (four levels) against the four levels of offsite (Table 4) described by Gibb and Isack (2003) suggests that Singapore's approach to DfMA portrays prefabrication as a game-changing technology. In other words, what has been known as the four levels of prefabrication is now being rebranded as a modern game changing DfMA technology. Sharafi, Rashidi, Samali, Ronagh, and Mortazavi (2018) noted the level of easy assembly can be a decision-making factor to determine the level of prefabrication. Gao, Low, and Nair (2018) identified a list of factors affecting DfMA adoption, classifying them into six categories, ranging from industry factors to stakeholder factors. These influencing factors are not barriers per se. Rather, they reduce the complex nature of these game-changing DfMA technologies for construction into manageable but critical factors that need to be taken into consideration when the DfMA adoption strategy is laid out (Gao et al., 2018). Tan and Elias (2000), however, cautioned the high dependence on technology may cultivate a posture of technological passivity.

Table 3. Some DfMA elements (BCA, 2016).

\begin{tabular}{|c|c|}
\hline DfMA elements & Note \\
\hline 1. Cross Laminated Timber (CLT) & $\begin{array}{l}\text { Manufactured from wood, harvested from sustainably managed forests, and fabricated by binding layers of } \\
\text { timber at } 90 \text { degrees with structural adhesives to produce a solid timber panel; Able to be used as either } \\
\text { structural or non-structural components in buildings }\end{array}$ \\
\hline 2. Integrated Prefabricated M\&E & $\begin{array}{l}\text { Mechanical, electrical and distribution items prefabricated either as linear lengths, flat assemblies or integrated } \\
\text { within volumetric modules }\end{array}$ \\
\hline 3. Precast \& Prefabricated Elements & $\begin{array}{l}\text { Elements that are manufactured in a controlled environment and that are generally of better quality than in-situ } \\
\text { elements (e.g. staircases, facades, refuse chutes, parapets, etc.) }\end{array}$ \\
\hline 4. Prefabricated Bathroom Unit (PBU) & $\begin{array}{l}\text { A bathroom unit fabricated and preassembled off-site complete with finishes, sanitary fittings, bathroom } \\
\text { cabinets, concealed pipework, conduits and ceiling before being delivered and installed in position on site }\end{array}$ \\
\hline $\begin{array}{l}\text { 5. Prefabricated Pre-Finished Volumetric } \\
\text { Construction (PPVC) }\end{array}$ & $\begin{array}{l}\text { Assembly of whole rooms, modules or apartment units complete with internal finishes and fixtures that are } \\
\text { prefabricated off-site and installed on-site to form modular apartments }\end{array}$ \\
\hline
\end{tabular}


Table 4. Levels of off-site.

\begin{tabular}{llll}
\hline Level & \multicolumn{1}{c}{ Category } & Definition & Singapore's DfMA elements \\
\hline 1 & $\begin{array}{c}\text { Component manufacture } \\
\text { \& sub-assembly }\end{array}$ & Items always made in a factory and never considered for on-site production & \\
2 & $\begin{array}{c}\text { Non-volumetric pre- } \\
\text { assembly }\end{array}$ & $\begin{array}{l}\text { Pre-assembled units which do not enclose usable space (e.g. timber roof trusses) } \\
\text { Volumetric pre-assembly }\end{array}$ & $\begin{array}{c}\text { Cross Laminated Timber (CLT); } \\
\text { Integrated Prefabricated M\&E }\end{array}$ \\
& $\begin{array}{c}\text { Pre-assembled units which enclose usable space and are typically fully factory } \\
\text { finished internally, but do not form the buildings structure (e.g. toilet and } \\
\text { bathroom pods) }\end{array}$ & $\begin{array}{c}\text { Precast \& Prefabricated Elements; } \\
\text { Prefabricated Bathroom Unit (PBU) }\end{array}$ \\
& Whole buildings (modular) & $\begin{array}{c}\text { Pre-assembled volumetric units which also form the actual structure and fabric of } \\
\text { the building (e.g. prison cell units or hotel/motel rooms) }\end{array}$ & $\begin{array}{c}\text { Prefabricated Pre-Finished } \\
\text { Volumetric Construction (PPVC) }\end{array}$ \\
\hline
\end{tabular}

Source: Gibb (1999) and Gibb and Isack (2003).

\section{DfMA: typical benefits}

The benefits of DfMA in manufacturing and construction are of similar fashion. Ashley (1995) cited a survey of DfMA users conducted by Boothroyd Dewhurst Inc. found the typical results include: a $51 \%$ reduction in parts count, a $37 \%$ decrease in parts cost, a $50 \%$ faster time-to-market, a $68 \%$ improvement in quality and reliability, a $62 \%$ drop in assembly time, and a $57 \%$ reduction in manufacturing cycle time. More successful stories of applying DfMA can be seen in Boothroyd (1994). The main highlight is that in each case, a considerable reduction in the part count has been achieved, resulting in a simpler product (Boothroyd, 1994). In construction, Chen and Lu (2018) noted, much less research has provided empirical evidence of the effects of DfMA in construction, with the exception of several examples that applied DfMA principles to various types of facilities and found benefits that were qualitative in nature, such as reducing material most, minimizing assembly and transport cost, etc. However, from a holistic perspective, the overall cost intensity is the main cause of the slow uptake of DfMA. This has been well documented through wealth literature when DfMA is viewed as technology. Ho, Peng, and Shea (2018) mentioned six cost drivers, namely: the need to set up a manufacturing and holding yard for DfMA components, the need for a tower crane with higher capacity to hoist 25-30 ton concrete DfMA modules (considerably more costly than typical capacity tower cranes), moulds that are unlikely to be recycled or reused for another project, staff training, and others. Arguably, this cost estimation does take the social cost factors (Çelik, Kamali, \& Arayici, 2017; Gilchrist \& Allouche, 2005) into account for DfMA adoption. A small selection of the reported DfMA case studies in construction, mainly from the UK is shown in Table 5. The industry is aware of the cost issues. The reported benefits seem to focus on the time performance. It was reported, the first major benefit of DfMA is a significantly reduced construction programme (Laing O’Rourke, 2013) followed by better quality and safety. RIBA (2013) found a $20-60 \%$ reduction in construction programme time, and greater programme certainty. In addition, Chen and $\mathrm{Lu}$ (2018) reported the DfMA-oriented curtain wall (CW) design was able to save more than seven minutes in assembly time for one CW unit with better workmanship.

\section{Discussion}

\section{Challenges}

Boothroyd (1994) used a metaphor 'over-the-wall' approach to describe the design process where the designer throws the design over a wall to the manufacturing engineers who then have to deal with the various manufacturing problems arising because they are not involved. The application of DfMA overcomes this problem by breaking the 'wall' so that designers can consult manufacturing engineers at the design stage (Boothroyd, 1994), and later forming proprietary methodologies to help them in design (Fox et al., 2001). In the building industry, the traditional design can be described as 'designing from first principles' where the design process comprises progressive layering with successive levels of details until all materials are specified and their incorporation are represented on working drawings (Pasquire \& Connolly, 2003). Mechanical \& Electrical (M\&E) service tends to be detailed much later than structure and fabric elements and usually well into the construction phase. This is the stage where production and assembly problems are likely to occur and hence requests are made for design changes (Boothroyd, 1994). Unlike their counterparts in manufacturing, the building designers have not been provided with equivalent methodologies, but rely on the varying experience of individuals (Fox et al., 2001), and some think in frames (Atkin, 1993). In Luiten and Fischer's (1998) words, typical building project with a sequential or linear product development process where communication is only possible one way from designers to builders. In this case, no feedback from construction is possible. The consequence of these is that designers may not be considering all reasonable potential design solutions, and therefore, may 
Table 5. Examples of DfMA applications in construction.

\begin{tabular}{|c|c|c|c|c|c|c|}
\hline $\begin{array}{l}\text { Parties } \\
\text { involved } \\
\text { (Contractor) }\end{array}$ & Project type & Off-site & $\begin{array}{c}\text { Application of } \\
\text { Digital } \\
\text { Technology }\end{array}$ & Location & Key features of DfMA & Benefits of DfMA \\
\hline $\begin{array}{l}\text { Laing } \\
\text { O'Rourke }\end{array}$ & $\begin{array}{r}\text { Salford and Wigan } \\
\text { Building Schools }\end{array}$ & $70 \%$ & Yes & Salford, UK & $\begin{array}{l}\text { - Development of a library of } \\
\text { standard structural components } \\
\text { - DfMA development including } \\
\text { prefabricated service risers, } \\
\text { prefabricated services horizontal } \\
\text { distribution units and packaged } \\
\text { plantrooms }\end{array}$ & $\begin{array}{l}\text { - Considerably } \\
\text { reduction of time in } \\
\text { the production of } \\
\text { component } \\
\text { drawings. }\end{array}$ \\
\hline $\begin{array}{l}\text { Laing } \\
\text { O'Rourke }\end{array}$ & $\begin{array}{l}\text { Water Treatment } \\
\text { Plant }\end{array}$ & $\begin{array}{c}300 \text { 'module } \\
\text { transportable } \\
\text { packages' }\end{array}$ & Yes & $\begin{array}{c}\text { Queensland, } \\
\text { Australia }\end{array}$ & $\begin{array}{l}\text { - Offsite pre-assembled piping } \\
\text { and electrical distribution } \\
\text { 'modules' } \\
\text { - } 5 \text { plant locations, } 32 \text { module } \\
\text { groups, } 262 \text { modules in total } \\
\text { including kits-of-parts }\end{array}$ & $\begin{array}{l}\text { - } 70 \% \text { reduction in site } \\
\text { labour } \\
\text { - } 60 \% \text { in project } \\
\text { delivery time for } \\
\text { DfMA elements }\end{array}$ \\
\hline $\begin{array}{l}\text { Mott } \\
\text { Macdonald }\end{array}$ & $\begin{array}{l}\text { Davyhulme } \\
\text { Wastewater } \\
\text { Treatment }\end{array}$ & $\begin{array}{l}5000 \text { precast } \\
\text { elements }\end{array}$ & Yes & Manchester & $\begin{array}{l}\text { - Development of a catalogue of } \\
\text { more than } 80 \text { DfMA products, } \\
\text { predominantly for the water } \\
\text { sector, including all the } \\
\text { elements needed to create a } \\
\text { sewage pumping station as well } \\
\text { as more general components. } \\
\text { - Close liaison between the } \\
\text { design disciplines to ensure } \\
\text { each component provides the } \\
\text { necessary structural and } \\
\text { functional requirements }\end{array}$ & $\begin{array}{l}\text { - Material waste } \\
\text { reduction } \\
\text { - } 3 \text { month shorter in } \\
\text { project delivery } \\
\text { - Time savings of } 50 \text { - } \\
90 \%\end{array}$ \\
\hline $\begin{array}{l}\text { Laing } \\
\text { O'Rourke }\end{array}$ & Leadenhall Building & $85 \%$ & Yes & London, UK & $\begin{array}{l}\text { - } \text { First time used DfMA in earnest } \\
\text { - } 20 \text { revisions before a final } \\
\text { version was agreed in terms of } \\
\text { floor systems }\end{array}$ & $\begin{array}{l}\text { - Increased the quality } \\
\text { of materials and } \\
\text { installation, } \\
\text { - } \text { reduced site waste, } \\
\text { - } \text { reduced overall } \\
\text { deliveries to site by } \\
50 \%\end{array}$ \\
\hline $\begin{array}{l}\text { Carillion and } \\
\text { Skanska }\end{array}$ & $\begin{array}{l}\text { Battersea Power } \\
\text { Station site } \\
\text { redevelopment } \\
\text { (Phase I) }\end{array}$ & $\begin{array}{l}\text { Manufactured } \\
540 \text { utility } \\
\text { cupboards }\end{array}$ & Virtual-reality & Slough, UK & $\begin{array}{l}\text { - The 'kit of parts' construction } \\
\text { system } \\
\text { - Manufacturing takes place in a } \\
\text { temporary facility, rented for the } \\
\text { duration of the offsite } \\
\text { programme }\end{array}$ & $\begin{array}{l}\text { - } 60 \% \text { reduction in } \\
\text { time } \\
\text { - } 4 \% \text { cost saving } \\
\text { - } 73 \% \text { fewer defects }\end{array}$ \\
\hline
\end{tabular}

Source: AECOM (2017), Built Offsite (2017, Enzer (2015), Construction Manager (2015), Laing O'Rourke (2013), and RIBA (2013).

overlook something which may be worth having (Atkin, 1993). Worse, as Bröchner, Josephson, and Kadefors (2002) put it, the architect and engineers lacked knowledge of exact number of parts, order of assembly, how parts are supposed to be assembled, and how long an on-site operation takes. These are the main challenges for DfMA taken as a process or evaluation model.

\section{Design guidelines}

Clearly the above observation suggests that DfMA has not been consciously applied in construction. Fox et al. (2001) explained little formal (reference) material that is either used or needed during the early design stage. Therefore, DfMA rules, principles, and best practices should be communicated to building designers. A good way to begin with is the development of design guidelines. Edwards (2002) concluded that design guidelines are one of the main sources of explicit knowledge on the practice of design. Gerth et al. (2013) added that DfMA utilizes deep production knowledge and experience from multiple disciplines, functions as a feedback loop between the design and the manufacturing. Each operation takes time and has an associated cost (Edwards, 2002). Therefore, qualitative and general principles of DfMA, together with Koskela's (2000) flow principles, can be a good reference point for construction firms to customize their own DfMA guidelines. Some principles may be already known by the designer. Other principles can be triggered by tasks or events as the design proceeds (Edwards, 2002). The RIBA (2013), being the pioneer, lent its weight to the DfMA 
approach by creating an overlay to the RIBA Plan of Work 2013 that suggests how architects could weave offsite considerations into all stages, from strategic definition to handover and building use. In Singapore, Building \& Construction Authority (BCA) has identified DfMA as a key strategic thrust to raise the construction productivity, and published the prefabricated prefinished volumetric construction (PPVC) guidebook as the first instalment of a series of guidebooks on DfMA technologies (BCA, 2017b). Association and authority in the UK and Singapore have been forerunners to promoting the DfMA methods through guidebooks published for the industry. Empirical evidence like Gbadamosi et al. (2019) found the guidelines based on the DfMA and lean methods benefit the construction industry for efficient material selection, waste minimization during assembly and fast project delivery.

\section{Multidisciplinary team}

Many researchers (Ashley, 1995; Omigbodun, 2001) emphasized that the DfMA practice is applied by a multidisciplinary, including design engineers, manufacturing engineers, shop floor mechanics, suppliers' representatives, and specialists in production support, maintainability, and reliability. Syan and Swift (1994) wrote the chief among the underlying imperatives of DfMA approach is the team or simultaneous engineering approach in which all relevant components of manufacturing system, including outside suppliers, are made active participants in the design effort from the start. Fox et al. (2001) argued that in construction, only a few modes of building procurement will permit suppliers, subcontractors and consultants to meet during the early stages ode the design process. Chen and Lu (2018) pointed out it is easier to apply DfMA to projects delivered by Design-Build than to Design-BidBuild project. Similarly, Song, Mohamed, and AbouRizk (2009) agreed that early involvement of subcontractors and suppliers do face challenges in the contracting practices, but their case studies (Song et al., 2009) showed that fabricators are able to provide design assistance in optimization, modularization, and standardization in the early design stage. Dainty, Briscoe, and Millett (2001) proposed an integrated contractual system that ensures a parity of responsibilities and obligations would be desired. Chen and Lu (2018) acknowledged it is challenging to balance between benefits/ value derived from multi-disciplinary team to integrate knowledge as extensively as possible. But more importantly, the client organization and the architect need to accept that contractor and/or subcontractors can bring added value to their design process.

\section{Building information modelling (BIM)}

Historically, one of the DfMA thrusts is the development of a variety of computer-based and/or computer-aided design programs (i.e. CAD software) (Stoll, 1986). Edwards (2002) pointed out that most of the DfMA procedures in manufacturing settings today are computerized. Kremer (2018) noted programs and design software is an important platform required to deliver a DfMA value proposition that allow for assessment, design and adjudication of parts and elements that constitute the individual units. The advantage of computer support is that it aids the DfMA evaluation procedure by prompting the user, providing help screens in context and by conveniently documenting the analysis (Leaney, 1996). Once essential data is entered, various analysis, for example the 'what if analysis, are conducted to identify problematic areas as priorities for redesign. In construction, it is reasonable to believe that BIM can be critical to the success of DfMA (Cousins, 2014). BIM can be exploited in the design and manufacturing of prefabricated components (Nawari, 2012; Vähä, Heikkilä, Kilpeläinen, Järviluoma, \& Gambao, 2013) where in the 3D model, all individual building components are digitally available and their geometry as well as behaviour and properties are accurately represented. Chen and $\mathrm{Lu}$ (2018) reflected in their DfMA-oriented curtain wall design case which was developed by using Auto$\mathrm{CAD}$, and noted, the manual process of updating and reanalysing the design (i.e. recalculating the material cost) could have been improved by a more advanced digital parametric design platform. To tap on the potential of BIM for DfMA design, Yuan et al. (2018) proposed a DfMA oriented parametric design, which uses BIM as a digital platform, for prefabricated buildings. This novel design approach, as Yuan et al. (2018) claimed, realizes the coordination of building designers, manufacturing designers, and assembly professionals. The very first task of this design approach is to timely integrate the detailed information required by manufacture and assembly stages of precast component into design stage, i.e. geometry, structure, connection, manufacture process, assembly process, mechanical equipment (Yuan et al., 2018). Given all the associated information needed for the analysis of cost, structure, and assembly, this provides various opportunities to evaluate the 'assembly' efficiency, and feeds into the learning loop for continuous improvement purpose (Nawari, 2012). Again, the challenge here is the quality of the data or information that needed for BIM to assist the building designer to evaluating alternative designs as Fox et al. (2001) did caution that building designers have limited confidence over information (i.e. price books, 
manufacturer data) when they get it. Often, their decision-making of materials selection is likely to be based on rule-of-thumb instead of quantified comparisons of alternatives. Yuan et al. (2018) argued, architectural design firm can be a dominant party in the design team, but they have to cooperate with the other two parties, namely manufacturing and assembly technicians.

\section{Synergy of DFMA and Lean construction}

It has been noted that the key characteristics of DfMA rules are in line with the heuristic principles of flow concept of production as put forward by Koskela (2000). Taking this notion further, Gbadamosi et al. (2019) mapped the interrelationship between DfMA and lean construction based on their underlying principles. For a successful application, Fox et al. (2002) suggested DfMA rules to target on best available productivity/ quality improvement opportunities. For example, it seems both DfMA and lean recommended 'standardization' as a common principle to gain efficiency. Gerth et al. (2013, p. 141) wrote 'the key focus in DfMA is to reduce the production cost, mainly by reducing the number of parts, with the aim of reducing the number of assembly operations and the complexity in production management'. As Koskela (2000) implied other things being equal, the very complexity of a product or process increases the costs beyond the sum of the costs of individual parts or steps. Kremer (2018) noted, not only is parts standardization important to DfMA, the removal of elements and a reduction in the number of overall parts assist in reducing time in manufacturing and improving efficiency. This question, however, is what needs to be simplified, and how. According to Fox et al. (2002), the best opportunity of standard component designers/producers is to design their components for ease of manufacture, consolidation of parts, and simply assembly. Furthermore, Gbadamosi et al. (2019) found waste minimization is another common factor underpinned by DfMA and lean construction. Similarly, in Gerth et al.'s (2013) DfC framework, the second step is to identify typical problems and waste on site by using the data collection methods. The seven types of waste (Ohno, 1988) can be good examples to look for (Gerth et al., 2013). By understanding what these wastes (non-value added) activities are, it would be more meaningful to assist designers in understanding what kind of inefficient motions, and operation are associated with manufacturing and assemble. The production knowledge will help the building designers to evaluate how well the desired product characteristics can be achieved with the minimum of waste on site.

\section{Conclusion}

There are two main areas of manufacturing that construction can benefit from (Kagioglou et al., 1998), namely new product development and the operational/ production processes. Much has been discussed on the second area. Indeed, a number of production and operation philosophy and practices such as Just in Time (JIT), lean production and others originated in the manufacturing sector. This paper concentrates on the first, which related very closely to the design process, with a focus on design for manufacture and assembly (DfMA). This study begins with a review of DfMA in the manufacturing, and notes DfMA takes manufacturing and assembly into account during the product design, but also these considerations must occur as early as possible. The review of general principles of DfMA reveals that these principles are actually in line with the heuristic principles of Koskela's (2000) flow concept of production. Through a literature review, this paper discovered that DfMA can be deployed in three forms:

(1) A holistic design process that encompasses how structure or object will be manufactured and assembled guided with sets of principles;

(2) An evaluation system that can work with virtual design and construction (VDC) to evaluate the efficiency of manufacturing and assembly; and

(3) A game-changing philosophy that embraces the ever-changing to prefabrication and modular construction technologies.

This paper makes the following contributions. It adds to the body of DfMA knowledge in the construction industry. It extends the previous work of Fox et al. (2001) and Gerth et al. (2013), which only focus one of the perspectives discussed above, by proposing the application of DfMA in construction need to embrace these three perspectives holistically. Arguably, the last perspective which views DfMA as prefabrication technologies can quickly enable project team experience many benefits (i.e. reduction in construction programme time). However, taking off DfMA as effective and collaborative design process, together with an evaluation system are equally important as these are originally adopted in manufacturing. In the modern-day construction industry, with the rise of prefabrication and BIM, building designers should be working closely with engineers and fabricators, in a multidisciplinary team, to develop DfMA guides and evaluation metrics and digitally incorporated them into $3 \mathrm{D}$ model so that such useful information can assist building designers evaluating alternative designs. Prior to this, the 'over-the-wall' 
approach in design must be broken down by bringing the knowledge from the parties in the downstream up to the design stage. Early involvement or teamwork avoids many of the problems that arise.

\section{Notes}

1. Crown House Engineering became part of Laing O'Rourke in 2004 and today is one of the UK's leading building and infrastructure technology services providers, supplying a complete Building Services package.

2. Flat pack' solutions, which output a kit of parts that can be quickly assembled on site.

\section{Disclosure statement}

No potential conflict of interest was reported by the authors.

\section{ORCID}

Shang Gao (1) http://orcid.org/0000-0002-4161-5592

Ruoyu Jin (D) http://orcid.org/0000-0003-0360-6967

\section{References}

AECOM. (2017). Salford \& Wigan BSF Programme, UK. Retrieved from http://www.aecom.com/projects/salfordwigan-bsf-programme/.

Arif, M., Goulding, J., \& Rahimian, F. P. (2012). Promoting offsite construction: Future challenges and opportunities. Journal of Architectural Engineering, 18(2), 75-78.

Ashley, S. (1995). Cutting costs and time with DFMA. Mechanical Engineering, 117(3), 74.

Atkin, B. (1993). Stereotypes and themes in building designs: Insights for model builders. Construction Management and Economics, 11(2), 119-130.

Ballard, G., \& Howell, G. (1998). What kind of production is construction. Proceedings, 6th annual conference of the International Group for Lean Construction, Guaruja, Brazil.

BCA. (2016). BIM for DfMA (Design for Manufacturing and Assembly) essential guide. Singapore.

BCA. (2017a). Code of practice on buildable design. Singapore Building \& Construction Authority.

BCA. (2017b). Prefabricated prefinished volumetric construction. Singapore: BCA.

Blismas, N. G., Pendlebury, M., Gibb, A., \& Pasquire, C. (2005). Constraints to the use of off-site production on construction projects. Architectural Engineering and Design Management, 1(3), 153-162.

Blismas, N., Pasquire, C., \& Gibb, A. (2006). Benefit evaluation for off-site production in construction. Construction Management and Economics, 24(2), 121-130.

Bogue, R. (2012). Design for manufacture and assembly: Background, capabilities and applications. Assembly Automation, 32(2), 112-118.

Boothroyd, G. (1994). Product design for manufacture and assembly. Computer-Aided Design, 26(7), 505-520.

Boothroyd, G. (2005). Assembly automation and product design. Wakefield, Rhode Island: CRC Press.
Boothroyd, G., \& Dewhurst, P. (1987). Product design for assembly. Wakefield, RI: Boothroyd Dewhurst.

Bralla, J. G. (1999). Design for manufacturability handbook. New York, NY: McGraw-Hill.

Bridgewater, C. (1993). Principles of design for automation applied to construction tasks. Automation in Construction, 2(1), 57-64.

Bröchner, J., Josephson, P.-E., \& Kadefors, A. (2002). Swedish construction culture, management and collaborative quality practice. Building Research \& Information, 30(6), 392-400.

Built Offsite. (2017). Laing O'Rourke's DFMA in action. Built Offsite. Melbourne, Australia prefabAUS 2017.

Chen, K., \& Lu, W. (2018). Design for manufacture and assembly oriented design approach to a curtain wall system: A case study of a commercial building in Wuhan. China. Sustainability, 10(7), 2211.

Constance, J. (1992). DFMA: Learning to design for manufacture and assembly. Mechanical Engineering-CIME, 114(5), $70-75$.

Construction Manager. (2015). Skanska's 'flying factories' take off in Slough, Construction Manager Magazine, UK, CIOB.

Cousins, S. (2014). Leader of the pack. Construction Research and Innovation, 5(4), 16-21.

Crowley, A. (1998). Construction as a manufacturing process: Lessons from the automotive industry. Computers \& Structures, 67(5), 389-400.

Çelik, T., Kamali, S., \& Arayici, Y. (2017). Social cost in construction projects. Environmental Impact Assessment Review, 64, 77-86.

Dainty, A. R., Briscoe, G. H., \& Millett, S. J. (2001). Subcontractor perspectives on supply chain alliances. Construction Management \& Economics, 19(8), 841-848.

Dewhurst, N. P. (2010). DFMA the product, then lean the process. Proceedings from International Forum on Design for Manufacture and Assembly.

Edwards, K. (2002). Towards more strategic product design for manufacture and assembly: Priorities for concurrent engineering. Materials \& Design, 23(7), 651-656.

Enzer, M. (2015). DfMA - One of the keys to unlocking a more efficient industry. Retrieved from https://www.mottmac. $\mathrm{com} /$ views/dfma---the-key-to-a-more-efficient-industry.

Emmatty, F. J., \& Sarmah, S. (2012). Modular product development through platform-based design and DFMA. Journal of Engineering Design, 23(9), 696-714.

Fox, S., Marsh, L., \& Cockerham, G. (2001). Design for manufacture: A strategy for successful application to buildings. Construction Management and Economics, 19(5), 493-502.

Fox, S., Marsh, L., \& Cockerham, G. (2002). Constructability rules: Guidelines for successful application to bespoke buildings. Construction Management \& Economics, 20(8), 689-696.

Gao, S., Low, S. P., \& Nair, K. (2018). Design for manufacturing and assembly (DfMA): A preliminary study of factors influencing its adoption in Singapore. Architectural Engineering and Design Management, 14(6), 440-456.

Gbadamosi, A.-Q., Mahamadu, A.-M., Oyedele, L. O., Akinade, O. O., Manu, P., Mahdjoubi, L., \& Aigbavboa, C. (2019). Offsite construction: Developing a BIM-based optimizer for assembly. Journal of Cleaner Production, 215, 1180-1190.

Gerth, R., Boqvist, A., Bjelkemyr, M., \& Lindberg, B. (2013). Design for construction: Utilizing production experiences in development. Construction Management and Economics, 31(2), 135-150. 
Gibb, A. G. F. (1999). Off-site fabrication: Prefabrication, preassembly, and modularization. New York: Wiley.

Gibb, A., \& Isack, F. (2003). Re-engineering through preassembly: Client expectations and drivers. Building Research \& Information, 31(2), 146-160.

Gilchrist, A., \& Allouche, E. N. (2005). Quantification of social costs associated with construction projects: State-of-the-art review. Tunnelling and Underground Space Technology, 20(1), 89-104.

Goodier, C., \& Gibb, A. (2007). Future opportunities for offsite in the UK. Construction Management and Economics, 25(6), 585-595.

Goulding, J. S., Rahimian, F. P., Arif, M., \& Sharp, M. D. (2015). New offsite production and business models in construction: Priorities for the future research agenda. Architectural Engineering and Design Management, 11(3), 163-184.

Ho, K. M., Peng, L. J., \& Shea, M. (2018). Pre-fabricated Prefinished Volumetric Construction (PPVC) for residential projects. Singapore.

Jarkas, A. M. (2015). Effect of buildability on Labor productivity: A Practical quantification approach. Journal of Construction Engineering and Management, 142(2), 06015002.

Kagioglou, M., Cooper, R., Aouad, G., Sexton, M., Hinks, J., \& Sheath, D. (1998). Cross-industry learning: The development of a generic design and construction process based on stage/ gate new product development processes found in the manufacturing industry. Engineering design Conference, Brunel University.

Koskela, L. (1992). Application of the new production theory to construction (CIFE Technical Report \#72). USA: Stanford University.

Koskela, L. (2000). An exploration towards a production theory and its application to construction. Espoo: VTT Technical Research Centre of Finland.

KPMG. (2016). Smart construction - how offsite manufacturing can transform our industry. London.

Kremer, P. D. (2018). Design for Mass Customised Manufacturing and Assembly (DfMCMA): A framework for capturing off-site and on-site efficiencies in mass timber construction. Mass Timber Construction Journal, 1(1), 9-13.

Laing O'Rourke. (2013). The future of DfMA is the future of construction. Engineering Excellence Journal, 77, 44-73.

Leaney, P. G. (1996). Case experience with Hitachi, Lucas and Boothroyd-Dewhurst DFA methods. Design for X. In G. Q. Huang (Ed.), Design for X: Concurrent engineering imperatives (41-71). Dordrecht: Springer Netherlands.

Luiten, G. T., \& Fischer, M. A. (1998). Opportunities for computer-aided design for construction. Engineering, Construction and Architectural Management, 5(2), 127-136.

Mao, C., Shen, Q., Pan, W., \& Ye, K. (2013). Major barriers to off-site construction: The developer's perspective in China. Journal of Management in Engineering, 31(3), 04014043.

Nakamba, C. C., Chan, P. W., \& Sharmina, M. (2017). How does social sustainability feature in studies of supply chain management? A Review and Research Agenda. Supply Chain Management: An International Journal, 22(6), 522-541.

Nawari, N. O. (2012). BIM standard in off-site construction. Journal of Architectural Engineering, 18(2), 107-113.
O'Driscoll, M. (2002). Design for manufacture. Journal of Materials Processing Technology, 122(2), 318-321.

Ohno, T. (1988). Toyota production system: Beyond large-scale production. Cambridge, MA: Productivity Press.

Omigbodun, A. (2001). Value engineering and optimal building projects. Journal of Architectural Engineering, 7(2), 40-43.

Otto, K., \& Wood, K. (2001). Product design: Techniques in reverse engineering and new product development. Upper Saddle River, NJ: Prentice Hall.

Pan, W., \& Goodier, C. (2011). House-building business models and off-site construction take-up. Journal of Architectural Engineering, 18(2), 84-93.

Pasquire, C. L., \& Connolly, G. E. (2003). Design for manufacture and assembly. 11th Annual Conference of the International Group for Lean Construction, Virginia, USA.

Poh, P. S., \& Chen, J. (1998). The Singapore buildable design appraisal system: A preliminary review of the relationship between buildability, site productivity and cost. Construction Management \& Economics, 16(6), 681-692.

RIBA. (2013). RIBA Plan of work 2013 designing for manufacture and assembly. London: Royal Institute of British Architects (RIBA).

Sharafi, P., Rashidi, M., Samali, B., Ronagh, H., \& Mortazavi, M. (2018). Identification of factors and multi-criteria decision analysis of the level of modularization in building construction. Journal of Architectural Engineering, 24, 2.

Song, L., Mohamed, Y., \& AbouRizk, S. M. (2009). Early contractor involvement in design and its impact on construction schedule performance. Journal of Management in Engineering, 25(1), 12-20.

Stoll, H. W. (1986). Design for manufacture: An owerwiew. Applied Mechanics Reviews, 39(9), 1356.

Syan, C. S., \& Swift, K. G. (1994). Design for manufacture. In C. Syan, \& U. Menon (Eds.), Concurrent engineering (pp. 101-115). Dordrecht: Springer.

Tan, W., \& Elias, Y. (2000). Learning by doing in Singapore construction. Journal of Construction Research, 1(2), 151-158.

Tommelein, I. D. (1998). Pull-driven scheduling for pipe-spool installation: Simulation of lean construction technique. Journal of Construction Engineering and Management, 124 (4), 279-288.

Tranfield, D., Denyer, D., \& Smart, P. (2003). Towards a methodology for developing evidence-informed management knowledge by means of systematic review. British Journal of Management, 14(3), 207-222.

Trinder, L. (2018). Design for manufacture and assembly: Its benefits and risks in the UK water industry. Proceedings of the Institution of Civil Engineers - Management, Procurement and Law, 171(4), 152-163.

Vähä, P., Heikkilä, T., Kilpeläinen, P., Järviluoma, M., \& Gambao, E. (2013). Extending automation of building construction survey on potential sensor technologies and robotic applications. Automation in Construction, 36, 168-178.

Wee, B. V., \& Banister, D. (2016). How to write a literature review paper? Transport Reviews, 36(2), 278-288.

Yuan, Z., Sun, C., \& Wang, Y. (2018). Design for manufacture and assembly-oriented parametric design of prefabricated buildings. Automation in Construction, 88(April), 13-22. 